\title{
Strategic Management in Improving The Quality of Education in The Midst of The Covid-19 Pandemic
}

\author{
Yanthy Herawaty ${ }^{1}$, Rudi Hartono ${ }^{2}$, Heldy Ramadhan ${ }^{3}$ \\ \{yanthy.herawaty.purnama@ undira.ac.id ${ }^{1}$, \\ rudihartono311287@gmail.com ${ }^{2}$, heldyramadhan@iain- \\ surakarta.ac.id $\left.{ }^{3}\right\}$ \\ Faculty of Business Management, Universitas Dian Nusantara, Indonesia ${ }^{1}$, Faculty of \\ Education, Ibn Khaldun University,Indonesia ${ }^{2}$, Islamic Education Management Study \\ Program Postgraduate Faculty, IAIN Surakarta, Indonesia ${ }^{3}$
}

\begin{abstract}
This research aims to look at the phenomenon that exists in the midst of the covid-19 pandemic at this time the world of education must be managed strategically management to be able to choose among many management goods to produce the best management developed. This research was conducted in Madrasah Aliyah Argamakmur State and Madrasah Aliyah Negeri (MAN) Argamakmur. The approach used in this study is qualitative approach to multi-location studies. Data is collected through interviews, observations and documentation. The results of this study concluded that: Strategic planning of Madrasah Aliyah Negeri Kabupaten Argamakmur is carried out through activities, the formation of vision and mission formulations of teams, determination of vision and mission, analyzing opportunities, threats, obstacles, and alternative problem solving, opening enrichment classes, improving learningp, and improving the quality of educators. Strategic evaluations at Madrasah Aliyah Negeri Argamakmur are conducted through: official meetings, meetings with principals and committees, special meetings of principals and vice principals, teacher meetings, employees, and principals, and committee meetings. While in Madrasah Aliyah Negeri Argamakmur Regency is conducted through: official meetings, meetings with principals, and committees, special meetings of vice principals, teacher meeting activities, employees, and principal meetings.
\end{abstract}

Keyword: Strategic, Management, Education, Covid-19

\section{Introduction}

In the face of the COVID-19 pandemic, it is certainly necessary to management the pandemic and the role of the community. In Indonesia itself, the COVID-19 pandemic continues to experience an increase in cases. Even today it is already one of the highest case countries in Southeast Asia. Therefore the importance of the role and function of public health in the face of pandemics. Severe acute respiratory syndrome coronavirus 2 (SARSCoV-2) was first detected in December 2019. As I write this, the coronavirus disease 2019 (COVID-19) pandemic is hitting South Africa and events are unfolding fast as new measures are taken on a daily basis to contain its spread within communities. This article does not attempt to keep up with the latest announcements and news, but to share what we know about the virus and its clinical management. The article is targeted at primary care providers, general practitioners and family physicians [1].

Management with a public health approach needs to be done in the face of the COVID19 pandemic. Of course, the process of assessment, policy development, and assurance is key 
to dealing with this pandemic. The assessment and policy development process must be done quickly, precisely, and accurately. In the meantime, assurance must be ensured clearly and in full focus.

Strategic management is a young discipline within the broader field of management. It emerged in the early 1960s, based on different final courses in business schools on the problems of general management in firms, under the name of business policy [2]. Differentiation strategy is among the generic strategic approaches in building competitive advantage. Differentiation strategies are based on providing buyers with something that is different or unique, that makes the company's product or service distinct from that of its rivals [3] Strategic management is defined as the process of evaluation, planning, and implementation designed to maintain or improve competitive advantage. The process of evaluation is concerned with the external and internal environments. Planning involves developing business models, corporate direction, competitive tactics, international strategy, acquisitions, and collaborative action. The implementation phase requires leadership to build the appropriate organizational structure, develop management culture, control the strategic processes, and steer the organization through corporate governance [4].

Strategic management is an approach to strategizing by public organizations or other entities that integrates strategy formulation and implementation, and typically includes strategic planning to formulate strategies, ways of implementing strategies, and continuous strategic learning. Strategic management can help public organizations or other entities achieve important goals and create public value [5].

The schools are open systems. As with any other system, the school system also has inputs, processes, outputs, feedback, and there are sub-systems interact with its environment. If we consider "process", one of the subsystems, we can encounter its sub-systems which are based on four basis in cycle; these are management, education, cultural, and politics. According to reports prepared as a result of international exams, surveys and assessments, the most important factors that affect academic success in the educational process, the administration and faculty, school principals and teachers that come to the fore. In this study; the "school management" that affects and increases student academic success and the implications for its development is selected as a main problem and tried to be clarified the results obtained, evaluation findings, and proposals on the subject [6].

Education is at the center of attention for all components of this nation. Fundamental changes have been made by changing the constitution, education system law No. 02 of 1989 to Number 20 of 2003, followed by government regulation number 32 of 2013 on National Standards of Education. The National Technical Reference of Education (SNP) is a minimum criterion of the education system throughout the jurisdiction of the Unitary State of the Republic of Indonesia, with a scope consisting of 8 standards which include: content standards, process standards, graduate competency standards, Educator and personnel standards, Facilities and infrastructure standards, Management standards, Financing standards, and education assessment standards ( SNP, 2013).

The entire learning process of teaching face-to-face at all levels has been closed or diverted into an online system (online) to prevent transmission and break the link of this coronavirus outbreak [7]. Of course, this has a bad impact on the education system in Indonesia even the world, the limitations of interaction in the midst of this pandemic cause a lot of problems in the world of education. For school management, innovation means finding new methods to solve the problems faced in education, training and management services, and introducing changes to increase the quality of these services to compete with other schools. At the same time, it is also believed that schools can increase their productivity through [8].

Crisis management is a sudden and unpredictable situation that can threaten the survival of stakeholders and the ability of educational institutions (schools) to be able to save 
themselves from crisis. The characteristics of this management crisis are the uncertainty that occurs, uneven and inadequate information, the lack of oversight carried out, outside observations. This is what is happening in the world of education around the world due to the coronavirus pandemic.

Disruption in the direct learning process between students and teachers and the cancellation of learning assessments have an impact on the psychological of the student and the decrease in the quality of the student's skills. That burden is the responsibility of all elements of education, especially the state in facilitating the continuity of schools for all educational stakeholders to conduct distance learning. The Indonesian government is also required how to plan, prepare and cope with the recovery in the world of education in the future as a result of this coronavirus pandemic.

In this situation, education management is needed to maintain the continuity of the teaching learning process. The drastic change in learning system made changes to the learning process during this pandemic. The unevenness of education is the main reason why education management should be updated and continued to be developed in Indonesia under the current conditions.

The key to success is must-have and at the same time the most effective competitiveness is quality. Whoever has the quality then the opportunity to be able to be a winner will be very open. Therefore education must be managed with strategic management in order to choose among many good management to produce a management that is best to achieve the quality of education.

Strategic management is an art (skill), engineering, and science formulating, implicating, and evaluating and overseeing various functional decisions of organizations (business and non-businesses) that are always influenced by internal and external environments, which are constantly changing as well as giving the organization the ability to achieve its goals as expected [9]. The importance of society in determining strategic management becomes very dominant, because it can lead to an advantage or can even be a threat to educational institutions.

The role of educational institutions in improving education is strategic, in order to gain the trust of the community. The primary responsibility of the madrassa head is to improve the school curriculum. They should have good supervision in order to provide assistance in determining the needs of the school and work towards the desired changes [10]. Looking at some of the explanations above quality education found a unique un igure 2. Bootstrapping Test Results

ique one that can be found in two different schools namely Madrasah Aliyah Negeri Argamakmur North Bengkulu Regency. This school is a school that characterizes itself as an educational institution by establishing its institution as a madrassa that teaches education both public and Islamic subject matter. The community is increasingly interested in supporting their sons and daughters in this institution because Madrasah Aiyah Negeri Kunir also provides education that integrates academic and non-academic excellence as a provision for its students.

While Madrasah Aliyah Argamakmur State is also a madrassa that is very loved by the main community in addition to the quality of education is good also because the location is in the heart of the city I don't want to be in thehouse. Researchers are interested in studying the phenomenon that occurs in Madrasah Aliyah Argamakmur State, among others is because madrassas continuously make improvements to the quality of schools, one of which is by implementing excellent school programs that can improve the academic and non-academic abilities of students. In addition, Madrasah Aliyah Negeri (MAN) Argamakmur is also a madrassa that has great trust from the community to educate their children. From the above exposure, researchers then have a desire to study in depth how the two madrassas do strategic management to deliver their madrassas into quality madrassas. 


\section{Methods}

This research is a scripted study that describes, exposes and reports a state, an object or event without drawing a general conclusion [11]. It is possible for researchers to gather detailed and rich information that includes the dimensions of a case.

Another meaning about scripted research is to analyze and present facts systemically about the actual state of the object [12]. The approach used in this research is the Paedagogical approach, which is an approach taken from a science point ofview.

This research is a type offield research and is included in the category of qualitative research, because research is more directed to understand the phenomena associated with the formulation of problems.

Data collection methods in the form of interviews, observations, and documentation techniques. Interview technique is the process of obtaining information for research purposes by way of q\&a while face to face between interviewer and informant. Interviews are unstructured interviews and in-depth interviews. The observation technique used is participatory observation which is a method of data collection used to collect research data through observation and sensing.. Documentation techniques are one of the methods of data collection used in social research by tracing historical data.

Data analysis through a series of processes of organizing and sorting data into category patterns and basic description units can be formulated with hypothetical work as suggested by the data [13]. The data analysis in question is to systematically search and organize observations, interviews, records and documentation to improve researchers on the issues being examined in a way: data reduction; presentation of data; and withdrawal of conclusions/verifications.

\section{Results and Discussions}

Based on the research that researchers conducted in the above two madrassas can be obtained the following research results:

\section{Strategic Planning in Improving The Quality of Education}

According to [14] suggesting that strategic planning is a disciplined effort to make important decisions and actions that shape and direct how an organization or other identity is, what the organization or other identity will do and why the organization (other identity) works that way. Strategic planning is an important part of strategic management. Strategic planning is a key aspect of strategic management and can be considered a central pillar in strategic management.

Amin mentions the characteristics of the strategic planning process are as follows:

1) Planning concerns the future reach of decisions made now.

2) Strategic planning is a formal systematic effort to outline the main form of the company, its objectives, policies and strategies for achieving its objectives and the main form of the organization in question.

3) The strategic planning process is the most important means of making decisions for the company, so that the objectives and direction are also determined.

4) The strategic planning process is a peak management activity that continues continuously.

5) Strategic development is a planning structure that integrates strategic plans with long-term operational plans. 
6) A strategic process is a process of determining in advance what to do, when to do and how to do, and who will do.

7) Strategic perencaan produces a written document on a periodic basis.

8) Strategic development is the most important means of making decisions for a company.

9) Strategic planning is an attitude, "way of life" means planning to ask for a habit and the necessity to work based on future thoughts [15] .

10) Bryson divides the strategic planning process into ten steps, leading to action, results, and evaluation is: 1) Initiating and agreeing to a strategic planning process. 2) Clarify the organization's mandate. 3) Clarify the mission and values of the organization. 4) Assess the external environment. 5) Assess the internal environment. 6) Identify strategic issues facing the organization. 7) Formulate strategies for managing issues. 8) Create an effective organizational vision for the future. 9) Develop the implementation process. 10) Reassess strategic strategy and strategic planning process [15].

Strategic planning in Madrasah Aliyah Negeri (MAN) Argamakmur was taken from several planning that was seen as more profitable and agreed together by the head of madrassa with his team. The strategic planning is carried out through several activities, among others: the formation of a formulateam so that intensively planning can be done to the maximum. The formulation of vision and mission carried out by the formula team is carried out by adjusting the vision and mission that has existed with the circumstances or developments of the times. This is done so that the vision and mission arranged is always updated. Indirectly, there has also been an analysis of opportunities and threats to madrassas, but the intended analysis has not been compiled in a written document. A long-term plan has been drawn up that will be implemented within the four-year period as well as an annual plan drawn up at the beginning of each year. The improvement of learning continues to be carried out in order to exceed the standards of graduate completedness. Open bilingual classes as featured classes. Improving the quality of educators is also always planned in every annual planning.

While in Madrasah Aliyah Negeri Argamakmur strategic planning is carried out through the following activities: the formation of a team of vision and mission formulation by equipping competent elements in their field. Determination of vision and mission is short and clear and in accordance with changes in government policy. Analysis of opportunities and threats from the community as well as obstacles that occur until alternative problem solving has not been compiled in the analysis document. The procurement of facilities in the form of Ma'had and opened enricmant (enrichment) classes has been planned to improve the quality of learning, as well as improve the quality of educators so that the quality of education can be achieved.

\section{Implementation of Strategic Management in Improving The Quality of Education}

Strategy implementation is a management process that realizes its strategy in the form of programs, procedures, budgets and development strategies in the form of actions. Vision is a process that describes a series of formal school planning and goal setting activities and mission is the reason for the existence of an institution [16]. The strategy is a comprehensive plan integrating all resources and capabilities that have a long-term goal of winning the competition. However great a vision, mission, and strategy if not implemented of course that strategy will not be meaningful for the development of the school.

The strategic management process consists of stages: (1) Environmental Analysis, (2) Setting Vision, Mission \& Objectives, (3) Strategy Formulation, (4) Strategy Implementation, and (5) Strategy Evaluation. The strategic implementation in Madrasah Aliyah Negeri (MAN) Argamakmur is carried out through: the formula team consists of the head of madrassa, deputy head, 2 teachers and madrassa committee. The formulation of vision and mission is arranged using short and clear sentences so that it is easy to know the expected 
benchmarks. Analysis of opportunities and threats from the environment is discussed in the interen forum as the basis for determining policy, but has not been prepared in the written document, the long-term plan is prepared for the first 4 years while the annual plan has been arranged in an orderly manner every beginning of the year. Improving learning effectively, thinnest and efficiently continues with and opening Bilingual classes guided by professionals from LBB Kampung England "Mahesa" Pare Kediri Regency. Improving the quality of educators by the preparation of class X teaching devices in accordance with curriculum 2013 and class XI and XII in accordance with KTSP, MGMP each subject and workshop.

While in Madrasah Aliyah Negeri (MAN) Argamakmur,, out through: The formation of a division and mission team consisting of the head of madrassa, all deputy heads, 2 teachers and madrassa committee. Determination of vision and mission is also carried out when viewed as irrelevant. The analysis of student opportunities is known to many from outside the city of Blitar, the threat of obstacles and alternative problem solving has not been compiled in the swot analysis document, but is still in internal madrassa talks. Ma'had procurement was carried out to facilitate students. Opening Enricmant (enrichment) classes by adding 12 JP/week, special science courses, and effectiveness in learning, discipline and discipline has been done regularly. Quality Improvement of educators has been carried out by always preparing class X teaching devices in accordance with curriculum 2013 and class XI and XII in accordance with KTSP, MGMP also conducted every subject and workshop was also conducted at the beginning of the school year .

\section{Strategic Evaluation in Improving The Quality of Education}

The last component of strategic management is the evaluation and monitoring of the company's progress towards its strategic objectives.

Organizations that believe that the process is fairly complete after the plan is implemented will only find themselves encountering failure. It's important that organizations continue to monitor their progress.

Strategic Evaluation in Madrasah Aliyah Negeri (MAN) Argamakmur has been conducted through several agendas of office meetings, namely between the head of madrasah and the Ministry of Religious Affairs of madrasah education department or with the District Education Office North Bengkulu. This is to obtain the applicable education information and policies. Meetings with madrasah heads and committees and deputy heads are also held at least twice a year. Special meetings of madrasah heads and deputy heads have been conducted and are conditional. Meetings of teachers, employees, and madrassa heads, and committee meetings.

While in Madrasah Aliyah Negeri (MAN) Argamakmur is conducted through: service meetings, meetings with madrasah heads, committees, and waka, special meetings of madrasah and waka heads, teacher meetings, employees, and madrasah heads, and committee meetings.

\section{Conclusion}

Departing from the results of research conducted in MAN Kunir Blitar district and Madrasah Aliyah Negeri (MAN) Argamakmur above can be drawn conclusions, among others:

1. Strategic planning is carried out through several activities including: the formation of a formulateam, formulation of vision and mission, analysis of opportunities, and threats, long-term plans, annual plans, improving learning, opening Bilingual classes and improving the quality of educators. While in Madrasah Aliyah Negeri (MAN) 
Argamakmur strategic planning is carried out through activities, the formation of formulation teams, determination of vision and mission, analysis of opportunities, threats, obstacles and alternative problem solving, procurement of Ma'had, opening Enricmant classes (enrichment), improving learning, and improving the quality of educators;

2. Strategic implementation in Madrasah Aliyah Negeri (MAN) Argamakmur is carried out through: the formula team consists of the head of madrassa, waka, 2 teachers and madrassa committee, formation of formulation team, formulation of vision and mission, analysis of opportunities, and threats from the environment, long-term plan drawn up for 4 years, annual plan, improvement of learning effectively,tiped and efficiently, and opening Bilingual classes, accompaniedby professionals fromLBB Kampung England "Mahesa" Pare Kediri Regency. Improving the quality of educators by the preparation of class X teaching devices in accordance with curriculum 2013 and class XI and XII in accordance with KTSP, MGMP each subject and workshop. While in Madrasah Aliyah Negeri (MAN) Argamakmur, carried out through: the formulateam consists of madrasah heads, all waka, 2 teachers and madrasah committees, vision and mission determination, analysis of many student opportunities from outside Blitar city, threats, dali environment, obstacles and problem solving alternatives, procurement of Ma'had, opening Enricmant classes (enrichment) by adding $12 \mathrm{JP} /$ week, specialized IPA majors, and effectiveness in learning, discipline and discipline. Quality Improvement of educators by the preparation of class X teaching devices in accordance with curriculum 2013 and grades XI and XII according to KTSP, MGMP each subject and workshop.

3. Strategic Evaluation at MAN Kunir is carried out through: official meetings, meetings with madrasah heads, committees, and waka, special meetings for madrasah and waka principals, meetings for teachers, employees and madrasah heads, and committee meetings. Whereas at the Argamakmur State Madrasah Aliyah (MAN) this is carried out through: official meetings, meetings with madrasah heads, committees and waka, special meetings for madrasah and waka heads, meetings for teachers, employees and madrasah heads, and committee meetings.

Conclusion as stated above, the writer also compiles in a SWOT analysis which is an acronym for Strength, Weakness, Opportunity, and Threat. The following SWOT analysis clearly describes the external opportunities and threats faced by the two institutions and is adjusted according to their strengths and weaknesses. The following researchers present the Argamakmur SWOT matrix table for the Argamakmur State Madrasah Aliyah (MAN):

\section{Acknowledgements}

Acknowledgements. This study aims to provide an overview to everyone that there is a need for good strategic management in the field of education, especially in the midst of the current Covid-19 pandemic. all stake holders who have supported this research

\section{References}

[1] B. Mash, "Primary care management of the coronavirus," J. South African Fam. Pract., p. 145, 2020.

[2] L. Angela, "No Title,” Int. Corp. Strateg. Manag., pp. 67-68, 2013.

[3] O. Tony, "Differentiation Strategy And Impact On Business," Strateg. J. Bus. Soc. Sci., p. 89.

[4] T. Bonici, "Strategic Management and Evolutionary Theory," J. Wiley Encycl. Manag., p. 87, 2014. 
[5] J. Bryson, "Journal Strategic Management in Public Administration," Strateg. Manag. Public Adm., vol. 20, 2020.

[6] \& A. Haydar, "THE IMPORTANCE OF SCHOOL MANAGEMENT HAS BEEN INCREASING.," Int. J. New Trends Educ. Their Implic., vol. 97, 2019.

[7] Siswanto, Pengantar Manajemen. 2016.

[8] M. Sagir, "Innovational Leadership in School Management," Int. J. ÜNIVERSITEPARK, p. 125.

[9] Akdon., Strategic Management for Educational Management. Bandung: Alfabeta., 2016.

[10] S. I. Fachrudi, Administrasi Sekolah dan Administrasi Pendidikan. Malang: Ilmu Pendidikan Malang., 2015.

[11] K. Kartono, Pengantar Metodologi Riset Sosial. Bandung: Mandar Maju., 2000.

[12] Anwar., Metode Penelitian. Yogyakarta: Pustaka Belajar, 2019.

[13] L. J. Moloeng, Metodologi Penelitian Kuaitatif. Bandung: Rosda Karya.

[14] J. M. Bryson, Journal Strategic Planning for Public and Nonprofit Organization. Fransico: Josses Boyess., 2018.

[15] A. W. Tunggak, Manajemen Suatu Pengantar. Jakarta: Rineka Cipta.

[16] Y. Antariksa, "Diambil kembali dari Melejitkan Kinerja Bisnis dengan Formula." 2019. 